\title{
On the Study of Ca and Mg Deintercalation from Ternary Tantalum Nitrides
}

\author{
Roberta Verrelli, ${ }^{\dagger, \ddagger}$ Ashley Philip Black, ${ }^{\dagger \dagger}$ Carlos Frontera, ${ }^{\dagger}$ (i) Judith Oró-Solé, ${ }^{\dagger}$

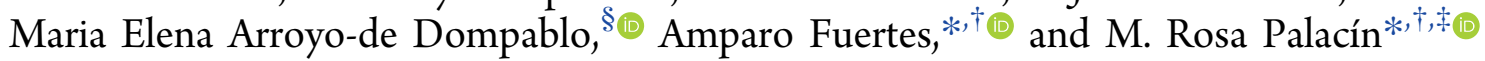 \\ ${ }^{\dagger}$ Institut de Ciència de Materials de Barcelona (ICMAB-CSIC) Campus UAB, E-08193 Bellaterra, Catalonia, Spain \\ ${ }^{\ddagger}$ ALISTORE-ERI European Research Institute, CNRS FR 3104, Hub de l'Energie, Rue Baudelocque, 80039 Amiens Cedex, France \\ ${ }^{\S}$ Departamento de Química Inorgánica, Facultad de Cc. Químicas, Universidad Complutense de Madrid, 28040 Madrid, Spain
}

\author{
Supporting Information
}

\begin{abstract}
Layered $\mathrm{CaTaN}_{2}$ and $\mathrm{MgTa}_{2} \mathrm{~N}_{3}$ and cubic $\mathrm{Mg}_{2} \mathrm{Ta}_{2} \mathrm{~N}_{4}$ were prepared by direct solid state reaction from the binary nitrides $T_{3} \mathrm{~N}_{5}$ and $\mathrm{A}_{3} \mathrm{~N}_{2}$ (A: Mg, Ca). CaTaN ${ }_{2}$ showed a slight Ca deficiency ( 0.11 moles per formula), and a monoclinic distortion from previously reported $R \overline{3} m$ symmetry, with space group $C 2 / m$ and cell parameters $a=5.4011(2), b=$ $3.1434(1), c=5.9464(2) \AA$ and $\beta=107.91(3)^{\circ} . \mathrm{Ca}^{2+}$ and $\mathrm{Mg}^{2+}$ deintercalation was investigated in the three compounds both chemically and electrochemically. No significant $\mathrm{Mg}^{2+}$ extraction could be inferred for $\mathrm{MgTa}_{2} \mathrm{~N}_{3}$ and $\mathrm{Mg}_{2} \mathrm{Ta}_{2} \mathrm{~N}_{4}$, neither after reaction with $\mathrm{NO}_{2} \mathrm{BF}_{4}$ nor after electrochemical oxidation at $100{ }^{\circ} \mathrm{C}$ in alkyl carbonate electrolytes. Rietveld refinement of the X-ray powder diffraction pattern of chemically oxidized $\mathrm{Ca}_{0.89} \mathrm{TaN}_{2}$ indicates a decrease of the Ca content to 0.34 concomitant to the disappearance of the monoclinic distortion and expansion of the interlayer space from 5.658 to $5.762 \AA$, space group $R \overline{3} m$ and cell parameters $a=3.1103(1)$ and $c=17.287(1) \AA$. Deintercalation in this compound was also achieved electrochemically at $100{ }^{\circ} \mathrm{C}$. Results of density functional theory calculations seem to indicate that reaction mechanisms for $\mathrm{CaTaN}_{2}$ oxidation additional and/or alternative to deintercalation are taking place, which is likely related to the loss of crystallinity observed upon oxidation and the irreversibility of the process.
\end{abstract}

\section{INTRODUCTION}

The transition from mono- to multivalent ion-based batteries is a key strategy to substantially enhance the energy density of currently available battery technologies, especially if metal anodes can be used. ${ }^{1}$ This concept becomes particularly attractive if earth-abundant and nontoxic metals are used as the overall battery technology would benefit from reduced cost and lower environmental impact. $\mathrm{Ca}$ and $\mathrm{Mg}$ are the fifth and eighth most abundant elements on the earth's crust, respectively, and the metals display theoretical volumetric energy densities of 3833 and $2073 \mathrm{~mA} \mathrm{~h} / \mathrm{mL}$, significantly larger than that of graphite, which is used as the negative electrode material in most commercial lithium ion batteries $(\sim 800 \mathrm{~mA} \mathrm{~h} / \mathrm{mL}){ }^{2}$ On the positive electrode side, divalent charge carriers would enable to double the capacities when compared to single valent ones for the same amount of reacted ions. Alternatively, reaction of only a half of the ions would be needed to achieve the same capacity. These prospects have been prompting increased interest from the scientific community, with $\mathrm{Mg}$ batteries having deserved the most attention so far. ${ }^{1}$ Progress in this topic is difficult, as significant bottlenecks exist both at a fundamental and technical level, and the understanding of the multivalent battery chemistry is still elusive in many aspects. Indeed, know-how gained in the development of Li-ion batteries cannot be directly imported and even a reliable electrochemical full cell setup is missing. ${ }^{3}$ On the crystal chemistry side, unraveling materials allowing fast and reversible ion mobility is a major challenge to address. The main issues arise from the high polarizing character of multivalent ions inducing strong Coulombic interactions within the electrode host framework and high (de)-solvation energy barriers, which dramatically affect the electrode intercalation kinetics and power performances. The use of $\mathrm{Mo}_{6} \mathrm{~S}_{8-y} \mathrm{Se}_{y}(y=1,2)$ Chevrel phases exhibiting fast and reversible $\mathrm{Mg}^{2+}$ migration as positive electrode materials represents a milestone in $\mathrm{Mg}$ battery chemistry, ${ }^{4}$ despite its redox potential being rather low. A vast array of other materials, including layered and spinel oxides, chalcogenides, Prussian blue analogues, vanadates, silicates, and polyanionic phosphates, have been studied, but none of them has resulted in suitable performance. ${ }^{1}$ Calcium systems are even less explored, as the feasibility of reversible calcium plating/ stripping got only recently unveiled. ${ }^{5,6}$ Encouraging results have been achieved with traditional layered materials such as $\mathrm{TiS}_{2}$, for which reversible insertion of $\mathrm{Ca}^{2+}$ at $100{ }^{\circ} \mathrm{C}$ has been recently demonstrated. ${ }^{7}$ Traditional layered oxides such as

Received: March 20, 2019

Accepted: May 9, 2019

Published: May 22, 2019 
Table 1. Synthesis Conditions for Tantalum Alkaline Earth Ternary Nitrides

\begin{tabular}{|c|c|c|c|c|c|c|}
\hline phase & reactants & $\mathrm{A} / \mathrm{Ta}(\mathrm{A}: \mathrm{Ca}, \mathrm{Mg})$ & $T\left({ }^{\circ} \mathrm{C}\right)$ & reaction time $(\mathrm{h})$ & atmosphere sample holder & refs \\
\hline $\mathrm{CaTaN}_{2}$ & $\mathrm{Ca}_{3} \mathrm{~N}_{2} ; \mathrm{Ta}_{3} \mathrm{~N}_{5}$ & $1.2 / 1$ & 1080 & 20 & $\mathrm{~N}_{2}$ flow, Mo crucible & this work \\
\hline $\mathrm{CaTaN}_{2}$ & $\mathrm{Ca}\left(\mathrm{NH}_{2}\right)_{2} ; \mathrm{Ta}_{3} \mathrm{~N}_{5}$ & 1 to $1.15 / 1$ & 1450 & 3 & $\mathrm{~N}_{2}, \mathrm{Nb}$ crucible & 18 \\
\hline $\mathrm{MgTa}_{2} \mathrm{~N}_{3}$ & $\mathrm{Mg}_{3} \mathrm{~N}_{2} ; \mathrm{Ta}_{3} \mathrm{~N}_{5}$ & $1.2 / 2$ & 850 & 20 & $\mathrm{~N}_{2}$ flow, Mo crucible & this work \\
\hline $\mathrm{MgTa}_{2} \mathrm{~N}_{3}$ & $\mathrm{Mg}(\mathrm{NH})_{2} ; \mathrm{Ta}_{3} \mathrm{~N}_{5}$ & $1.2 / 2$ & 1200 & 24 & $\mathrm{~N}_{2}$ flow, $\mathrm{Ni}$ crucible & 31 \\
\hline $\mathrm{Mg}_{2} \mathrm{Ta}_{2} \mathrm{~N}_{4}$ & $\mathrm{Mg}_{3} \mathrm{~N}_{2} ; \mathrm{Ta}_{3} \mathrm{~N}_{5}$ & $1 / 1$ & 850 & 20 & $\mathrm{~N}_{2}$ flow, Mo crucible & this work \\
\hline $\mathrm{Mg}_{2} \mathrm{Ta}_{2} \mathrm{~N}_{4}$ & $\mathrm{Mg}(\mathrm{NH})_{2}$ or $\mathrm{Mg}_{3} \mathrm{~N}_{2} ; \mathrm{Ta}_{3} \mathrm{~N}_{5}$ & $6 / 1$ & 1050 & 24 & $\mathrm{~N}_{2}$ flow, Mo crucible & 31 \\
\hline
\end{tabular}

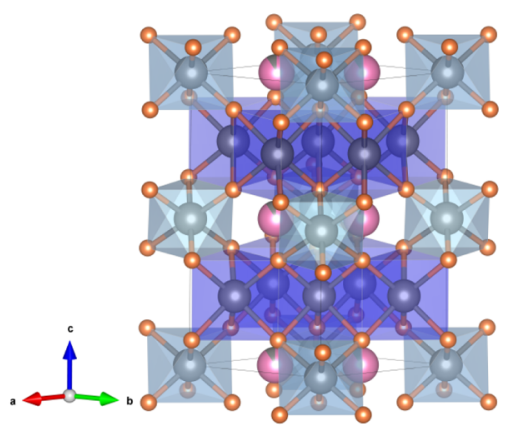

(A)

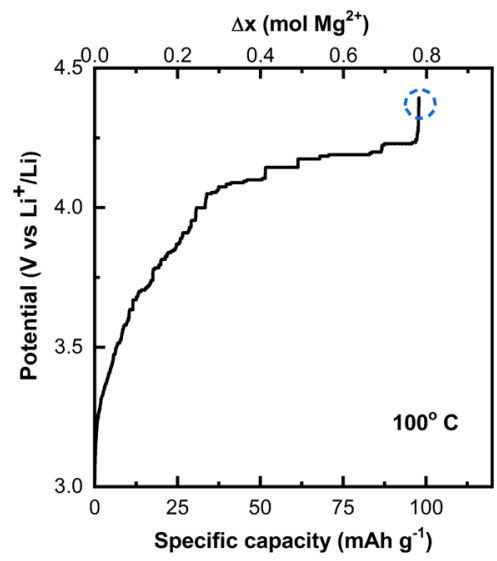

(C)

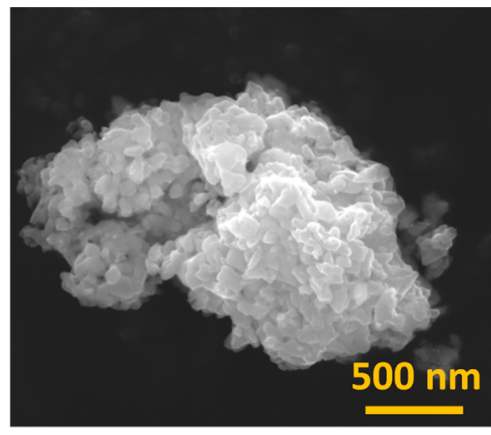

(B)

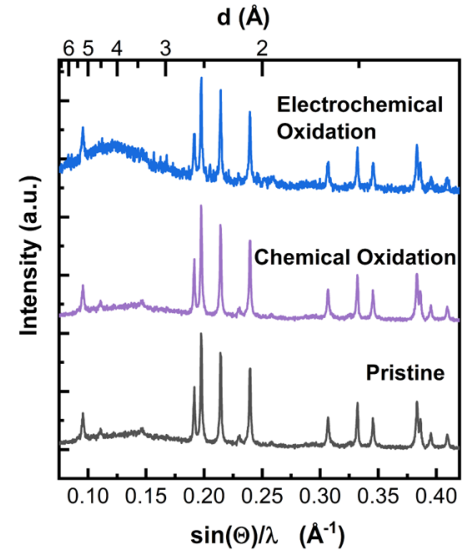

(D)

Figure 1. (A) Refined crystal structure of $\mathrm{MgTa}_{2} \mathrm{~N}_{3} ; \mathrm{N}, \mathrm{Mg}$, and $\mathrm{Ta}$ atoms are represented as orange, pink, and gray spheres. (B) Backscattered electron SEM micrograph of $\mathrm{MgTa}_{2} \mathrm{~N}_{3}$ powder. (C) Characteristic EPS potential profile vs specific capacity (bottom axis) and vs moles of virtually extracted $\mathrm{Mg}^{2+}$ (top axis), calculated considering that this is the only redox phenomenon taking place, for $\mathrm{MgTa}_{2} \mathrm{~N}_{3}$ electrode (with $15 \%$ wt of Super $\mathrm{P}$ carbon) in $\mathrm{Li}$ cell, with $1 \mathrm{~m} \mathrm{LiBOB}, \mathrm{EC} / \mathrm{PC}(1: 1 \mathrm{vol})$ electrolyte at $100{ }^{\circ} \mathrm{C}$ and $\mathrm{C} / 100$ rate and corresponding ex situ X-ray powder diffraction patterns (D). Diffraction patterns of the pristine and chemically oxidized samples are also shown in (D) for comparison.

$\mathrm{V}_{2} \mathrm{O}_{5}$ and $\mathrm{MoO}_{3}$ have been recently revisited for applications in Ca batteries: while poor (if any) $\mathrm{Ca}^{2+}$ intercalation has been proved in $\mathrm{V}_{2} \mathrm{O}_{5},{ }^{8}$ reversible electrochemical activity has been reported for $\mathrm{MoO}_{3} \cdot{ }^{9}$ Calcium transition metal ternary oxides have also drawn increasing attention: while too high $\mathrm{Ca}^{2+}$ migration barriers were determined for $\mathrm{CaMoO}_{3}$ and $\mathrm{CaMn}_{2} \mathrm{O}_{4}{ }^{10}$ electrochemical extraction of $\mathrm{Ca}^{2+}$ from $1 \mathrm{D}$ $\mathrm{Ca}_{3} \mathrm{Co}_{2} \mathrm{O}_{6}$ was achieved at high potential $(3.2-3.6 \mathrm{~V}$ vs $\mathrm{Ca})$, encouraging further optimization of the cathode and electrolyte compositions to achieve reversibility of the process. ${ }^{11}$

Within this research context, we decided to further explore non-oxidic compounds, turning our attention to ternary $\mathrm{A}_{x} \mathrm{Ta}_{y} \mathrm{~N}_{z}$ (A: $\left.\mathrm{Mg}, \mathrm{Ca}\right)$ tantalum nitrides. As compared to transition metal oxides, nitrides exhibit analogous crystal chemistry and a higher degree of covalency of the metalanion bonds, which results into unique chemical, magnetic, and optical properties. ${ }^{12}$ The high covalency of transition metal nitrides can be conceived as a tool to mitigate coulombic interactions with multivalent ions and hence facilitate their solid state migration. Furthermore, the high electronic conductivity exhibited by several transition metal nitrides could play a key role in promoting fast multivalent ion migration kinetics, in agreement with what has been recently evidenced for the $\mathrm{Mg}_{x} \mathrm{Zr}_{2} \mathrm{~S}_{4}$ thiospinel phase, ${ }^{13}$ exhibiting, despite its large unit cell volume and almost zero-strain upon insertion, lower $\mathrm{Mg}^{2+}$ diffusion coefficient than the $\mathrm{Mg}_{x} \mathrm{Ti}_{2} \mathrm{~S}_{4}$ phase $^{14}$ as a consequence of its much lower electronic conductivity. While covalency is also expected to result in a penalty in the redox operating voltage, this can be in principle compensated by the proper selection of transition metal redox centers. Although few reports on the study of ternary alkali transition metal nitrides as Li-ion battery electrode materials exist, $^{12,15}$ such compounds have not been considered for multivalent technologies, the only exception being $\mathrm{MgMoN}_{2}$, 


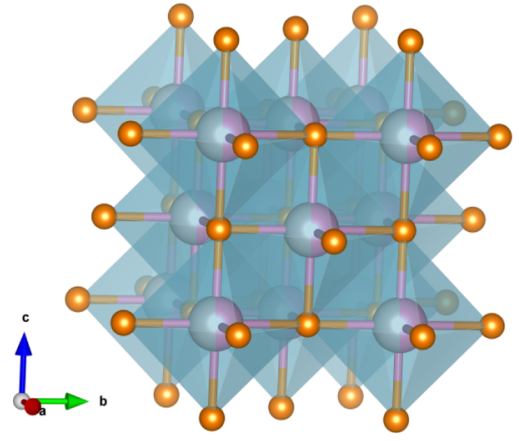

(A)

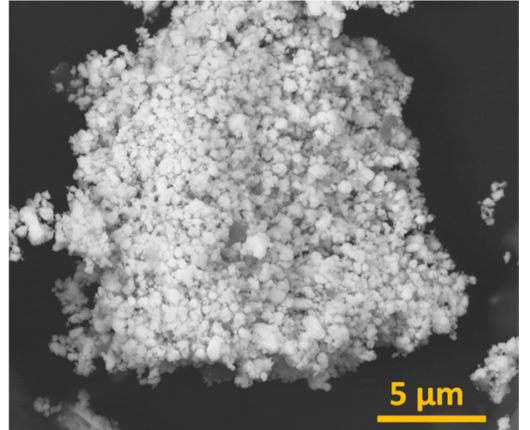

(B)

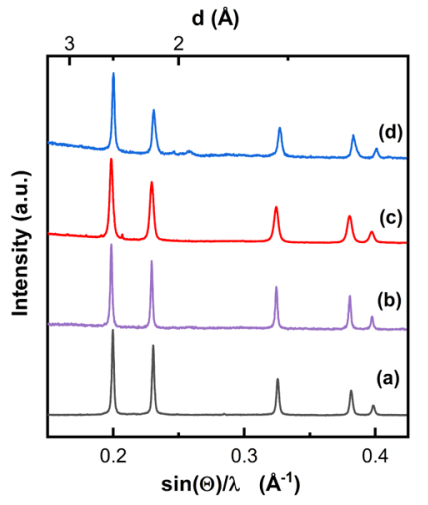

(C)

Figure 2. Refined crystal structure (A) and backscattered electron SEM micrographs (B) of $\mathrm{Mg}_{2} \mathrm{Ta}_{2} \mathrm{~N}_{4}{ }^{31}$ prepared at $1080{ }^{\circ} \mathrm{C}$ from binary nitrides. (C) X-ray powder diffraction patterns of pristine (a), chemically (b) and electrochemically oxidized (c) and reduced (d) $\mathrm{Mg}_{2} \mathrm{Ta}_{2} \mathrm{~N}_{4}$ samples.

for which $\mathrm{Mg}^{2+}$ extraction was not possible. ${ }^{16}$ Among the available alkaline earth metal transition metal nitrides, the ternary $\mathrm{A}-\mathrm{Ta}-\mathrm{N}(\mathrm{A}: \mathrm{Ca}, \mathrm{Mg})$ system represents an interesting playground for research, as the electronic configuration of tantalum allows in principle to explore a broad spectrum of phase compositions, with potentially high operating voltage and high specific capacities. Hexagonal $\mathrm{Mg}_{1-x} \mathrm{Ta}_{2+x} \mathrm{~N}_{3}$ and cubic $\mathrm{Mg}_{2.6-x} \mathrm{Ta}_{2+x} \mathrm{~N}_{3}$ phases were originally prepared by Brokamp and Jacobs by solid state reaction between $\mathrm{Mg}\left(\mathrm{NH}_{2}\right)_{2}$ or $\mathrm{Mg}_{3} \mathrm{~N}_{2}$ and $\mathrm{Ta}_{3} \mathrm{~N}_{5} \cdot{ }^{17}$ Analogously, CaTaN was synthesized by Disalvo et al. ${ }^{18}$ from $\mathrm{Ca}\left(\mathrm{NH}_{2}\right)_{2}$ and $\mathrm{Ta}_{3} \mathrm{~N}_{5}$ and suggested to have rhombohedral symmetry, being isostructural to $\alpha-\mathrm{NaFeO}_{2}$.

Herein, we present a study of such phases prepared from $\mathrm{Ta}_{3} \mathrm{~N}_{5}$ and binary nitrides $\mathrm{A}_{3} \mathrm{~N}_{2}$ (A: $\mathrm{Mg}, \mathrm{Ca}$ ) instead of the alkaline earth amides as reactants, and determination of the crystal structure for the calcium compound. The feasibility of $\mathrm{Ca}$ and $\mathrm{Mg}$ ion extraction from $\mathrm{CaTaN}_{2}, \mathrm{MgTa}_{2} \mathrm{~N}_{3}$, and $\mathrm{Mg}_{x} \mathrm{Ta}_{2} \mathrm{~N}_{4}$ was studied both chemically and electrochemically. Finally, in light of the results achieved, the feasibility of $\mathrm{Ca}$ deintercalation form $\mathrm{CaTaN}_{2}$ is also investigated using first principles calculations within the density functional theory (DFT) approximation.

\section{RESULTS AND DISCUSSION}

The achievement of ternary transition metal nitrides is far from being trivial, as high temperatures and prolonged treatments are needed in order to obtain crystalline samples and nitrides are inherently less stable than oxides due to their lower free energies of formation. ${ }^{26-30}$ In the synthesis of alkaline or alkaline earth transition metal nitrides, these long thermal treatments may result in significant losses of the most electropositive metal, which trigger the control over the product composition. The list of the ternary $\mathrm{Ca}$ and $\mathrm{Mg}$ tantalum nitrides studied in this work and of the experimental conditions employed for their synthesis is given in Table 1, together with the synthetic methods previously reported.

2.1. Magnesium Tantalum Nitrides. 2.1.1. $\mathrm{MgTa}_{2} \mathrm{~N}_{3}$. Attempts to extract $\mathrm{Mg}^{2+}$ from this phase were carried out both by chemical oxidation with $\mathrm{NO}_{2} \mathrm{BF}_{4}$ and by electrochemical methods at room temperature and $100{ }^{\circ} \mathrm{C}$. The characteristic potential versus capacity signature of the $\mathrm{MgTa}_{2} \mathrm{~N}_{3}$ electrode (15\% wt of Super P carbon) upon extended oxidation using an electrochemical potential spectroscopy (EPS) protocol at 100 ${ }^{\circ} \mathrm{C}$ in $\mathrm{Li}$ three-electrode cell [in $1 \mathrm{~m}$ LiBOB, ethylene carbonate (EC)/propylene carbonate (PC) 1:1 vol electrolyte] is shown in Figure 1C. A plateau-like region centered at about 4.2 $\mathrm{V}$ versus $\mathrm{Li}^{+} / \mathrm{Li}$ is observed in the oxidation profile, with a capacity approaching $100 \mathrm{~mA} \mathrm{~h} \mathrm{~g}{ }^{-1}$ (corresponding to about $0.8 \mathrm{~mol}$ of virtually extracted $\mathrm{Mg}^{2+}$ considering this as the only redox reaction taking place).

$\mathrm{MgTa}_{2} \mathrm{~N}_{3}$ was obtained by reacting $\mathrm{Mg}_{3} \mathrm{~N}_{2}$ and $\mathrm{Ta}_{3} \mathrm{~N}_{5}$ in $1: 2$ mol ratio at $850{ }^{\circ} \mathrm{C}$ for $20 \mathrm{~h}$ (see the Experimental Section for details). The as-prepared sample consists of homogenous micrometric aggregates of sub-micrometric and nanometric particles (see Figure $2 \mathrm{~B}$ ). The $\mathrm{Mg} / \mathrm{Ta}$ ratio determined from energy-dispersive $\mathrm{X}$-ray (EDX) spectroscopy was 0.45 with distribution of both elements being homogeneous (see Figure S1D). The Rietveld refinement using synchrotron X-ray diffraction (SXRD) patterns of the as-prepared sample is depicted in Figure S1A. Refinement has been done starting from previously reported structure with $P 6_{3} / \mathrm{mcm}$ space 
group. ${ }^{31}$ The refined cell parameters are $a=5.2106(2) \AA$ and $c$ $=10.4328(4) \AA$, which are in agreement with those previously reported for $\mathrm{Mg}_{1-x} \mathrm{Ta}_{2+x} \mathrm{~N}_{3}$ (ca. $\left.0<x<0.06\right)$. A Mg/Ta ratio slightly lower than $1 / 2$ could be inferred by the refinement of the occupation factors, while a nitrogen content of $9.6 \%$ wt was obtained by elemental analysis (i.e., approaching theoretical $9.8 \%$ wt value for $\mathrm{MgTa}_{2} \mathrm{~N}_{3}$ ). The crystal structure of $\mathrm{MgTa}_{2} \mathrm{~N}_{3}$ is represented in Figure 1A. It consists of $\left(\mathrm{TaN}_{2}\right)^{3-}$ layers between which both $\mathrm{Mg}^{2+}$ and $\mathrm{Ta}^{5+}$ ions occupy octahedral holes. The structure exhibits partial cation ordering, as Wyckoff position $4 \mathrm{~d}$ is mainly occupied by $\mathrm{Mg}^{2+}$ ions (i.e., for ca. $90 \%$ by $\mathrm{Mg}$ and $10 \%$ by $\mathrm{Ta}$ ) while positions $2 \mathrm{a}$ and $6 \mathrm{~g}$ are occupied only by tantalum. Some of the peaks in the SXRD patterns of the as-prepared sample (such as the 104 reflection at $d=2.258 \AA$ corresponding to $\sin (\theta) / \lambda=0.2214$ $\AA^{-1}$, see Figure S1B in the Supporting Information) exhibited a broad, asymmetric shape which prevented proper fitting by Rietveld refinement, neither by considering micro-absorption nor anisotropic strain effects. Such anisotropic broadening might be due to the presence of stacking faults, in line with observations in other layered compounds reported in the literature. $^{32}$ This is also consistent with the observation of streaking along $[001]^{*}$ in the electron diffraction patterns (see Figure S1F in the Supporting Information), which indicate stacking disorder along $c$.

The ex situ X-ray powder diffraction patterns of the $\mathrm{MgTa}_{2} \mathrm{~N}_{3}$ sample collected after the electrochemical and chemical oxidation tests are shown in Figure 1D. Compared with the pristine phase, neither peak shifts nor formation of extra phases are observed, this pointing to insignificant (if any) $\mathrm{Mg}$ de-insertion from $\mathrm{MgTa}_{2} \mathrm{~N}_{3}$, even under the severe oxidizing conditions employed and the electrochemical capacity observed being related to side reactions most likely involving electrolyte decomposition. Attempts to insert additional $\mathrm{Mg}^{2+}$ ions in the $\mathrm{MgTa}_{2} \mathrm{~N}_{3}$ structure were carried out by electrochemical reduction in $\mathrm{Mg}$ cells at $100{ }^{\circ} \mathrm{C}$, using a $0.3 \mathrm{M} \mathrm{Mg}(\mathrm{TFSI})_{2}$, EC/PC 1:1 electrolyte, which resulted in very low capacities and no changes in the $\mathrm{X}$-ray powder diffraction patterns.

2.1.2. $\mathrm{Mg}_{2} \mathrm{Ta}_{2} \mathrm{~N}_{4} \cdot \mathrm{Mg}_{2} \mathrm{Ta}_{2} \mathrm{~N}_{4}$ was obtained by solid state reaction at $1080{ }^{\circ} \mathrm{C}$ from $\mathrm{Ta}_{3} \mathrm{~N}_{5}$ and $\mathrm{Mg}_{3} \mathrm{~N}_{2}$ in 1:1 molar ratio (see the Experimental Section for details). The as-prepared $\mathrm{Mg}_{2} \mathrm{Ta}_{2} \mathrm{~N}_{4}$ exhibits a cation-disordered cubic crystal structure (Figure 2A) with $\mathrm{Mg}$ and $\mathrm{Ta}$ in octahedral coordination and cell parameter $a=4.35329(6) \AA$, as determined by Rietveld refinement of the SXRD data (see Figure S2A in the Supporting Information. Refinement was made using $F m \overline{3} m$ space group as reported in ref 26). An $\mathrm{Mg} / \mathrm{Ta}$ ratio of about 0.8 and 0.7 was obtained by EDX analysis, and $\mathrm{N}$ content of $9.5 \%$ wt was obtained from chemical analysis, in agreement with the nominal composition. A typical scanning electron microscopy (SEM) micrograph of the $\mathrm{Mg}_{2} \mathrm{Ta}_{2} \mathrm{~N}_{4}$ sample is shown in Figure $2 \mathrm{~B}$, displaying nanometric particles forming micrometric size aggregates with distribution of $\mathrm{Mg}$ and $\mathrm{Ta}$ being homogeneous (see Figure S2B).

When subjected to oxidation using an electrochemical potential spectroscopy (EPS) protocol at $100{ }^{\circ} \mathrm{C}$ in Li threeelectrode cells in $1 \mathrm{~m} \mathrm{LiBOB}, \mathrm{EC} / \mathrm{PC} 1: 1 \mathrm{vol}$ electrolyte, the electrodes containing $\mathrm{Mg}_{2} \mathrm{Ta}_{2} \mathrm{~N}_{4}$ exhibited a potential profile displaying a plateau around $4.2 \mathrm{~V}$ versus $\mathrm{Li}^{+} / \mathrm{Li}$ and specific capacities close to $90 \mathrm{~mA} \mathrm{~h} \mathrm{~g}$ corresponding to $\Delta x$ of virtually de-inserted $\mathrm{Mg}^{2+}$ of about 0.7 mol. However, no significant change in the $\mathrm{X}$-ray powder diffraction pattern was observed, neither after electrochemical nor after chemical oxidation, which points at the amount of $\mathrm{Mg}^{2+}$ deintercalated being insignificant, if any, and the electrochemical capacity observed being again related to side reactions. Attempts to electrochemically reduce $\mathrm{Mg}_{2} \mathrm{Ta}_{2} \mathrm{~N}_{4}$ in $\mathrm{Mg}$ cell were not successful either.

2.2. Magnesium Calcium Nitrides. $\mathrm{CaTaN}_{2}$ was prepared by solid state reaction at $1080{ }^{\circ} \mathrm{C}$ between $\mathrm{Ca}_{3} \mathrm{~N}_{2}$ and $\mathrm{Ta}_{3} \mathrm{~N}_{5}$ (see the Experimental Section for details) and was found to be stable in ambient air. We initially attempted to fit the X-ray powder diffraction pattern using the structural model previously reported by Balbarin et al. ${ }^{18}$ in space group $R \overline{3} \mathrm{~m} \cdot{ }^{33}$ However, several diffraction peaks show a clear splitting [e.g., reflections $012,015,018$ of $R \overline{3} \mathrm{~m}$ ] indicating lower symmetry. As an alternative, we used the structural model with monoclinic space group $\mathrm{C} 2 / \mathrm{m}$ that was reported for $\mathrm{Na}_{x} \mathrm{FeO}_{2} .{ }^{25}$ This provided a better fitting of the X-ray diffraction data and split reflections. The observed and calculated X-ray diffraction patterns are plotted in Figure 3.

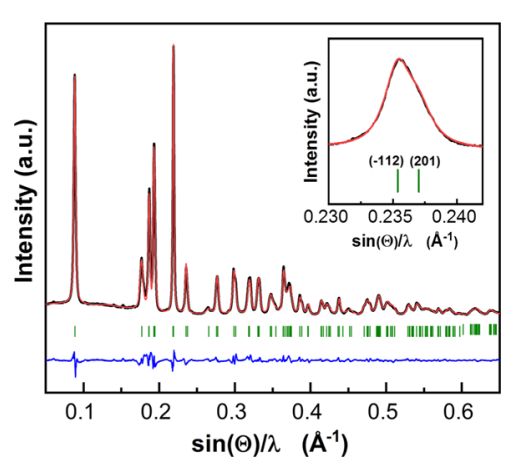

Figure 3. Observed and calculated SXRPD patterns of $\mathrm{Ca}_{0.89} \mathrm{TaN}_{2}(\lambda$ $=0.4133 \AA$ ) in space group $\mathrm{C} 2 / \mathrm{m}$. Vertical ticks denote the Bragg positions. Inset: Zoom of the ( 113$)$ and (202) doublet of $C 2 / m$ SG, a single reflection (015) would be present in this region for $R \overline{3} m$ SG.

The inset shows in detail the peak at ca. $0.236 \AA^{-1}$ corresponding to $\overline{1} 12 / 201$ reflections in $C 2 / m$ group and 015 reflection in $R \overline{3} \mathrm{~m}$, emphasizing the need of reducing the symmetry from rhombohedral to monoclinic. Results of the Rietveld refinement are listed in Table 2. This monoclinic

Table 2. Atomic Coordinates in Space Group C2/m for $\mathrm{Ca}_{0.89} \mathrm{TaN}_{2}$ from the Refinement of X-ray Diffraction Data at 298 K Using Radiation with $\lambda=0.4133 \AA^{a}$

\begin{tabular}{cclllll} 
atom & Wyckoff site & \multicolumn{1}{c}{$x$} & \multicolumn{1}{c}{$y$} & \multicolumn{1}{c}{$z$} & \multicolumn{1}{c}{$B_{\text {iso }}$} & Occ. factor \\
$\mathrm{Ca}$ & $2 \mathrm{~d}$ & 0 & 0.5 & 0.5 & $2.5(2)$ & $0.888(4)$ \\
$\mathrm{Ta}$ & $2 \mathrm{a}$ & 0 & 0 & 0 & $0.39(3)$ & 1 \\
$\mathrm{~N}$ & $4 \mathrm{i}$ & 0.278 & 0 & 0.795 & $0.8(3)$ & 1
\end{tabular}

${ }^{a}$ Refined cell parameters were $a=5.40108(2), b=3.1434(1), c=$ 5.9464(2) $\AA$ and $\beta=107.908(3)^{\circ}$. Agreement factors: $\chi^{2}=7.34 ; R_{\text {wp }}$ $=8.75 \% ; R_{\mathrm{Bragg}}=3.23 \%$. Average bond distances: $\left\langle d_{\mathrm{Ta}-\mathrm{N}}\right\rangle=2.15(3)$ $\AA ;\left\langle d_{\mathrm{Ca}-\mathrm{N}}\right\rangle=2.46(1) \AA$.

distortion might arise from Jahn-Teller effect (as reported in other layered oxides ${ }^{34}$ ) or, most likely in view of DFT results (see below), to vacancy/calcium ordering related to $\mathrm{Ca}$ deficiency $^{25,35,36}$ as typically occurs in the triangular lattice of $\mathrm{Na}$ sites in $\alpha-\mathrm{Na}_{x} \mathrm{FeO}_{2}$-type compounds. ${ }^{37,38}$ Besides, the background of the pattern indicates presence of a relevant amount of amorphous phase, which was quantified (by adding 


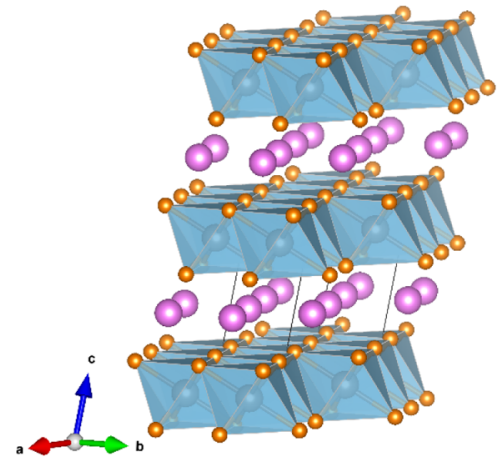

(A)

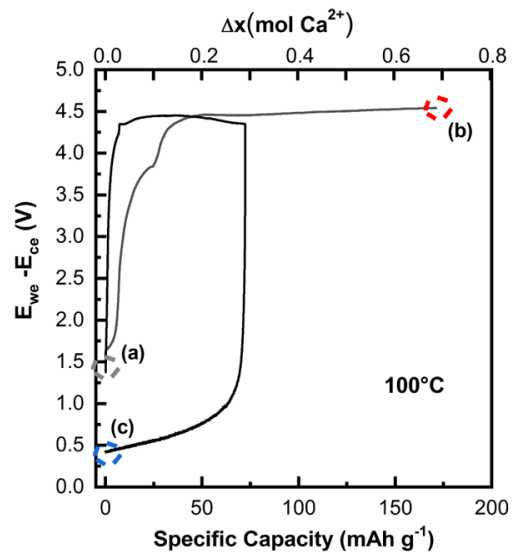

(C)

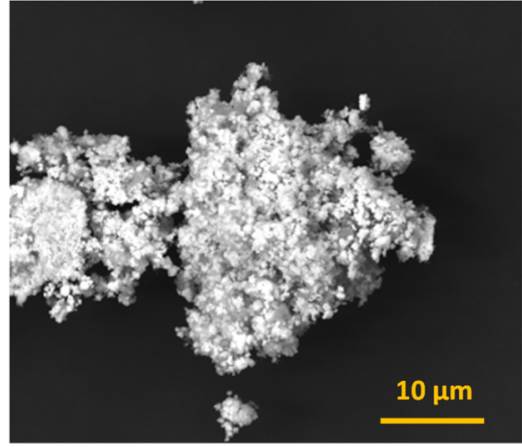

(B)

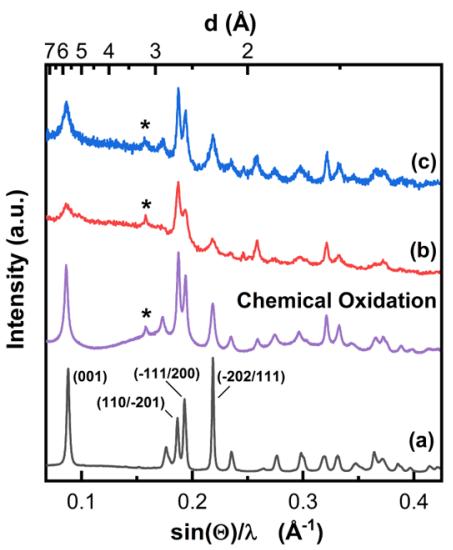

(D)

Figure 4. (A) Projection of the refined crystal structure of $\mathrm{Ca}_{0.89} \mathrm{TaN}_{2}$ along the [210] direction. $\mathrm{N}$, Ca, and Ta atoms are represented, respectively, as orange, magenta, and gray spheres. (B) Backscattered electron SEM image of $\mathrm{CaTaN}_{2}$ sample. (C) Characteristic GCPL voltage profiles vs specific capacity (bottom) and vs moles of virtually de-inserted $\mathrm{Ca}^{2+}(\Delta x)$ (top) of $\mathrm{Ca} / 0.45 \mathrm{M} \mathrm{Ca}\left(\mathrm{BF}_{4}\right)_{2}, \mathrm{EC} / \mathrm{PC}(1: 1 \mathrm{vol}) / \mathrm{CaTaN}_{2}$ (with $15 \%$ wt of Super P carbon) cells at $100{ }^{\circ} \mathrm{C}$ and $\mathrm{C} / 100$ rate and corresponding ex situ XRD patterns (b,c). (D) X-ray powder diffraction patterns of the pristine (a) and chemically oxidized samples are also displayed in (D). (*) denotes reflections corresponding to $\mathrm{CaF}_{2}$.

a $20 \%$ wt of $\mathrm{SiO}_{2}$ ) to be about $25 \%$ wt (see Supporting Information).

The $\mathrm{Ca}-\mathrm{N}$ and $\mathrm{Ta}-\mathrm{N}$ bond distances (see Table 2) are consistent with ionic radii values. The refinement of the occupation factors resulted in a slight $\mathrm{Ca}$ deficiency, with $\mathrm{Ca} /$ Ta ratio being $0.89(1)$. The presence of a minor impurity phase with main diffraction peaks at $\sin (\theta) / \lambda$ of ca. 0.208 and $0.246 \AA^{-1}$ was also detected, which may correspond either to $\mathrm{CaO}$ or $\mathrm{TaN}$. A Ca/Ta ratio close to 1 was also inferred from EDX with distribution of both elements being homogeneous (see Figure S5A), while a nitrogen content of $10.5 \%$ wt was determined by combustion analysis which is close $(1.82 \mathrm{~N}$ per formula) to that expected for the stoichiometry $\mathrm{Ca}_{0.89} \mathrm{TaN}_{2}$. These results are consistent with previous findings by Balbarin et al. who observed slight calcium deficiency and presence of $\mathrm{TaN}, \mathrm{TaN}_{0.1}$, or $\mathrm{Ca}_{2} \mathrm{TaN}_{3}$ as secondary phases. ${ }^{18}$

The crystal structure of $\mathrm{Ca}_{0.89} \mathrm{TaN}_{2}$ is represented in Figure 4A. Ca and Ta occupy alternating octahedral sites between close packed nitrogen slabs. The ordered distribution of cations within the layers has been reported to be at the origin of anisotropy of electrical resistivity. ${ }^{18}$

The as-prepared sample consists of micrometric aggregates of nanometric and sub-micrometric particles (Figure 4B) with homogeneous composition, as confirmed by EDX analysis. Attempts to extract $\mathrm{Ca}^{2+}$ from this phase were carried out, both by chemical oxidation reaction with $\mathrm{NO}_{2} \mathrm{BF}_{4}$ and by electrochemical methods. For the electrochemical experiments, $\mathrm{Ca}_{0.89} \mathrm{TaN}_{2}$ was mixed with conductive Super $\mathrm{P}$ carbon in $85: 15 \%$ wt ratio and subjected to electrochemical oxidation (de-insertion) tests in Ca metal cells under various conditions. As no electrochemical activity could be observed at RT, additional experiments were carried out at moderate temperature $\left(100{ }^{\circ} \mathrm{C}\right)$. Figure $4 \mathrm{C}$ displays the characteristic potential versus capacity profiles observed for $\mathrm{Ca}_{0.89} \mathrm{TaN}_{2}$ electrode at $100{ }^{\circ} \mathrm{C}$ and $\mathrm{C} / 100$ rate in $\mathrm{Ca}$ three-electrode cell with $\mathrm{Ca}$ reference and counter electrodes, in dry $0.45 \mathrm{M} \mathrm{Ca}\left(\mathrm{BF}_{4}\right)_{2}, \mathrm{EC} /$ PC 1:1 vol electrolyte. The potential signature displayed is the measured potential difference between the working and the counter electrodes (each measured vs passivated Ca reference). A full oxidation up to capacity values of about $170 \mathrm{~mA} \mathrm{~h} \mathrm{~g}^{-1}$ (corresponding to $\Delta x \mathrm{~mol}$ of virtually extracted $\mathrm{Ca}^{2+}$ ions of about 0.7 ) is reported in Figure 4C, together with an oxidation-reduction limited to lower values of delivered specific capacity (i.e. about $0.3 \mathrm{~mol}$ of virtually exchange $\mathrm{Ca}^{2+}$ ions). A plateau centered at about $4.5 \mathrm{~V}$ is observed upon oxidation with high polarization upon further reduction, both using tape or powder electrodes. A variation of the powder sample color from dark gray to light brown was detected both after the chemical and electrochemical oxidation tests, reasonably suggesting a variation of the tantalum oxidation 
state. The X-ray powder diffraction patterns of $\mathrm{Ca}_{0.89} \mathrm{TaN}_{2}$ at the end of the oxidation (de-insertion) process and after oxidation-reduction are reported in Figure 4D, together with the patterns corresponding to the pristine phase and the powder recovered after $10 \mathrm{~h}$ of reaction with $\mathrm{NO}_{2} \mathrm{BF}_{4}$ at $80{ }^{\circ} \mathrm{C}$ in acetonitrile (ACN).

Significant loss of crystallinity is observed, especially for the sample oxidized for longer time. An increase of the amorphous content from about $25 \%$ wt in the pristine sample to $50 \% \mathrm{wt}$ after oxidation was estimated from Rietveld refinement of the XRD data, by using an internal standard of $\mathrm{SiO}_{2}$ quartz (see Figures S3 and S4 in the Supporting Information). A strong decrease of the integrated intensity of the $\overline{2} 02 / 111$ reflections (104 in the $R \overline{3} m$ cell) $\left[\sin (\theta) / \lambda=0.219 \AA^{-1}, d=2.285 \AA\right]$ is clearly detected after the oxidation (see Figures $4 \mathrm{D}$ and 5),

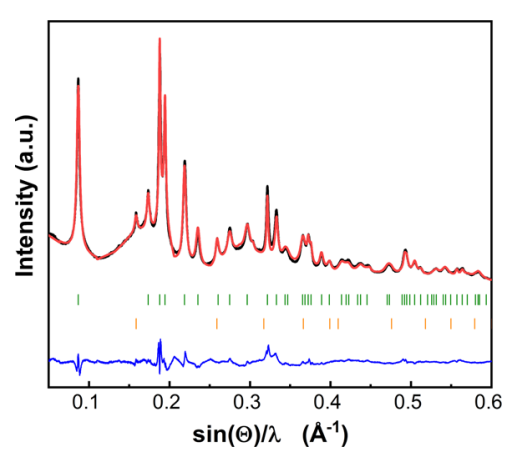

Figure 5. Observed and calculated $\mathrm{X}$-ray powder diffraction patterns of the chemically oxidized $\mathrm{Ca}_{0.89} \mathrm{TaN}_{2}$ phase. Vertical ticks denote the Bragg positions for $\mathrm{Ca}_{x} \mathrm{TaN}_{2}$ and for $\mathrm{CaF}_{2}$ impurity phase, respectively, in green (top) and in orange (bottom).

together with an increase in the intensity of the 001 reflection $\left(003\right.$ in $R \overline{3} m$ cell) $\left[\sin (\theta) / \lambda=0.089 \AA^{-1}, d=5.762 \AA\right]$ and changes in the relative intensities of $110 / \overline{2} 01[\sin (\theta) / \lambda=$ $0.187 \AA^{-1}, d=2.660 \AA, 101$ in the $R \overline{3} m$ cell] and $\overline{1} 11 / 200$ $\left[\sin (\theta) / \lambda=0.194 \AA^{-1}, d=2.570 \AA, 102\right.$ in the $R \overline{3} m$ cell $]$ reflections. An additional peak is observed at $\sin (\theta) / \lambda$ around $0.158 \AA^{-1}$, which is assigned to $\mathrm{CaF}_{2}$ derived from $\mathrm{BF}_{4}^{-}$ decomposition side reactions. The patterns corresponding to the chemically oxidized sample exhibit main peaks at values of $\sin (\theta) / \lambda$ of $0.087,0.188,0.195$, and $0.219 \AA^{-1}$ and can be fitted using a structural model with space group $R \overline{3} \mathrm{~m}$, with refined cell parameters $a=3.1103(1)$ and $c=17.287(1) \AA$ (see Figure 5 and Table 3 ). The stabilization of $R \overline{3} \mathrm{~m}$ structure in the chemically oxidized sample is consistent with the disappearance of the ordered vacancy-Ca configuration in the interlayer space, a feature well described in layered- $\mathrm{LiMO}_{2}$ materials where the lithium content drives the stabilization of

Table 3. Atomic Coordinates in Space Group $R \overline{3} m$ for Chemically Oxidized $\mathrm{Ca}_{x} \mathrm{TaN}_{2}$ from the Refinement of $\mathrm{X}$ ray Diffraction Data at $298 \mathrm{~K}$ Using Radiation with $\lambda=$ $0.41338 \AA^{a}$

\begin{tabular}{cccccc} 
atom & Wyckoff site & $x$ & $y$ & \multicolumn{1}{c}{$z$} & Occ. factor \\
$\mathrm{Ca}$ & $3 \mathrm{a}$ & 0 & 0 & 0 & $0.34(2)$ \\
$\mathrm{Ta}$ & $3 \mathrm{~b}$ & 0 & 0 & 0.5 & 1 \\
$\mathrm{~N}$ & $6 \mathrm{c}$ & 0 & 0 & $0.252(1)$ & 1
\end{tabular}

${ }^{a}$ Refined cell parameters were $a=3.1103(1)$ and $c=17.287(1) \AA$. Overall temperature factor $B=0.40(1) \AA^{2}$. Agreement factors: $\chi^{2}=$ 8.26; $R_{\mathrm{wp}}=12.7 \% ; R_{\mathrm{Bragg}}=4.43 \%$. particular Li-vacancy orderings and subsequent crystal symmetry changes. ${ }^{39,40}$ The changes in the cell parameters are similar to those observed in $\alpha-\mathrm{NaFeO}_{2}$ and $\mathrm{NaVO}_{2}$ during sodium deintercalation, ${ }^{41,42}$ which lead to layered phases with composition $\mathrm{Na}_{0.5} \mathrm{MO}_{2}$. Expanded $c$ axis (as mentioned, interlayer distance in $\mathrm{Ca}_{0.89} \mathrm{TaN}_{2}, 5.658 \AA$ would correspond to a hexagonal $c$ axis of $16.974 \AA$ ) resulting from increasing coulombic repulsions as the amount of ions in the interslab space decreases. The refined calcium occupancy for the chemically oxidized sample is $0.34(2)$, which agrees with the $\mathrm{Ca} / \mathrm{Ta}$ ratio of 0.4 obtained from XESD analysis. The poor crystallinity of the electrochemically oxidized sample prevents reliable refinement of the $\mathrm{Ca}$ occupancy. Nonetheless, the pattern is quite similar to the one of the chemically oxidized sample with $R \overline{3} m$ symmetry and cell parameters $a=3.107(1)$ and $c=17.363(5) \AA$, indicating a slightly larger expansion along $c$. The X-ray diffraction patterns of samples obtained by reduction of oxidized $\mathrm{Ca}_{0.89} \mathrm{TaN}_{2}$ did not show any additional change, which is a clear indication that calcium deintercalation is an irreversible process. Interestingly, very similar behavior has been reported for $\mathrm{NaTaN}_{2}{ }^{43}$ which was also oxidized chemically (in that case using $\mathrm{NO}_{2} \mathrm{PF}_{6}$ ) with significant amorphization and decrease in the relative intensity of some peaks with respect to others. In that case, no Rietveld refinement was possible even for pristine $\mathrm{NaTaN}_{2}$, despite a hexagonal cell being suggested and hence no values for sodium occupancy were available either. Yet, the $c$ contraction together with a gradual loss of crystallinity upon progressive oxidation was clearly established. Moreover, all attempts to reintroduce sodium in the structure were also unsuccessful. As for $\mathrm{NaTaN}_{2}$, tantalum is in its highest oxidation state, the authors do speculate that the redox reaction may involve nitrogen as well, despite not being able to confirm this hypothesis. The elemental analysis of the $\mathrm{Ca}_{0.89} \mathrm{TaN}_{2}$ sample after chemical oxidation revealed a nitrogen content of $7.7 \% \mathrm{wt}$, that is slightly lower than the one determined for the pristine phase (10.5\% wt) while distribution of $\mathrm{Ca}$ and $\mathrm{Ta}$ remains homogeneous (see Figure S5B).

At this point, a legitimate question was whether reversibility of the deintercalation process may be prevented by large calcium desolvation energies in the electrolyte used, as was suggested in the case of $\mathrm{Ca}_{3} \mathrm{Co}_{2} \mathrm{O}_{6},{ }^{11}$ or else the mechanism was more complex and involved some sort of decomposition upon oxidation, which may well explain the progressive amorphization.

In order to shed some light into this issue, calculations have been performed for the stoichiometric $\mathrm{CaTaN}_{2}$ and the hypothetical de-inserted phase $\mathrm{Ca}_{0.5} \mathrm{TaN}_{2}$ (see relevant results in Table 4). For $\mathrm{CaTaN}_{2}$, the monoclinic and hexagonal models yield similar total energies, with a negligible energy difference of $3 \mathrm{meV} / \mathrm{f} . u$. in favor of the latter (note that the energy difference is within the error range of the calculation). Interestingly, in both cases the optimized structure shows six almost equivalent $\mathrm{Ta}-\mathrm{N}$ distances excluding the presence of a Jahn-Teller distorted $\mathrm{Ta}^{1}$ cation. This is in line with detailed band structure calculations, ${ }^{4-46}$ showing that in $\mathrm{CaTaN}_{2}$ the three $t_{2 g}$-like Ta-based bands are practically degenerate, due to the very regular octahedral coordination for the $\mathrm{Ta}$ atoms.

In order to probe the role of the Ca-vacancy ordering in deviations from the $R \overline{3} m$ symmetry, we have considered a virtual composition $\mathrm{Ca}_{0.5} \mathrm{TaN}_{2}$ with $\mathrm{C} 2 / m$ symmetry $\mathrm{Ca}$ and vacancies ordered in rows (see Figure 6A). Noteworthy, in the optimized structure of this material, both the $\mathrm{TaN}$ and $\mathrm{CaN}$ 
Table 4. Calculated Lattice Parameters and Selected Bond Distances for $\mathrm{CaTaN}_{2}$ and $\mathrm{Ca}_{0.5} \mathrm{TaN}_{2}$

\begin{tabular}{|c|c|c|c|}
\hline & \multicolumn{2}{|r|}{$\mathrm{CaTaN}_{2}$} & \multirow{2}{*}{$\frac{\mathrm{Ca}_{0.5} \mathrm{TaN}_{2}}{\mathrm{C} 2 / m}$} \\
\hline & $R \overline{3} m$ & $\mathrm{C} 2 / \mathrm{m}$ & \\
\hline $\begin{array}{l}\text { lattice } \\
\text { parameters }\end{array}$ & $a=3.181 \AA, c=16.723 \AA$ & $a=5.506 \AA, b=3.179 \AA, c=5.874 \AA, \beta=108.216^{\circ}$ & $a=5.343 \AA, b=3.155 \AA, c=6.004 \AA, \beta=107.492^{\circ}$ \\
\hline $\begin{array}{l}\mathrm{Ca}-\mathrm{N} \text { distance } \\
(\AA)\end{array}$ & $2.4365 \times 6$ & $2.4351 \times 4,2.4366 \times 2$ & $2.4920 \times 4,2.5285 \times 2$ \\
\hline $\begin{array}{l}\mathrm{Ta}-\mathrm{N} \text { distance } \\
(\AA)\end{array}$ & $2.1862 \times 6$ & $2.1863 \times 2,2.1878 \times 4$ & $2.0848 \times 2,2.1445 \times 4$ \\
\hline
\end{tabular}
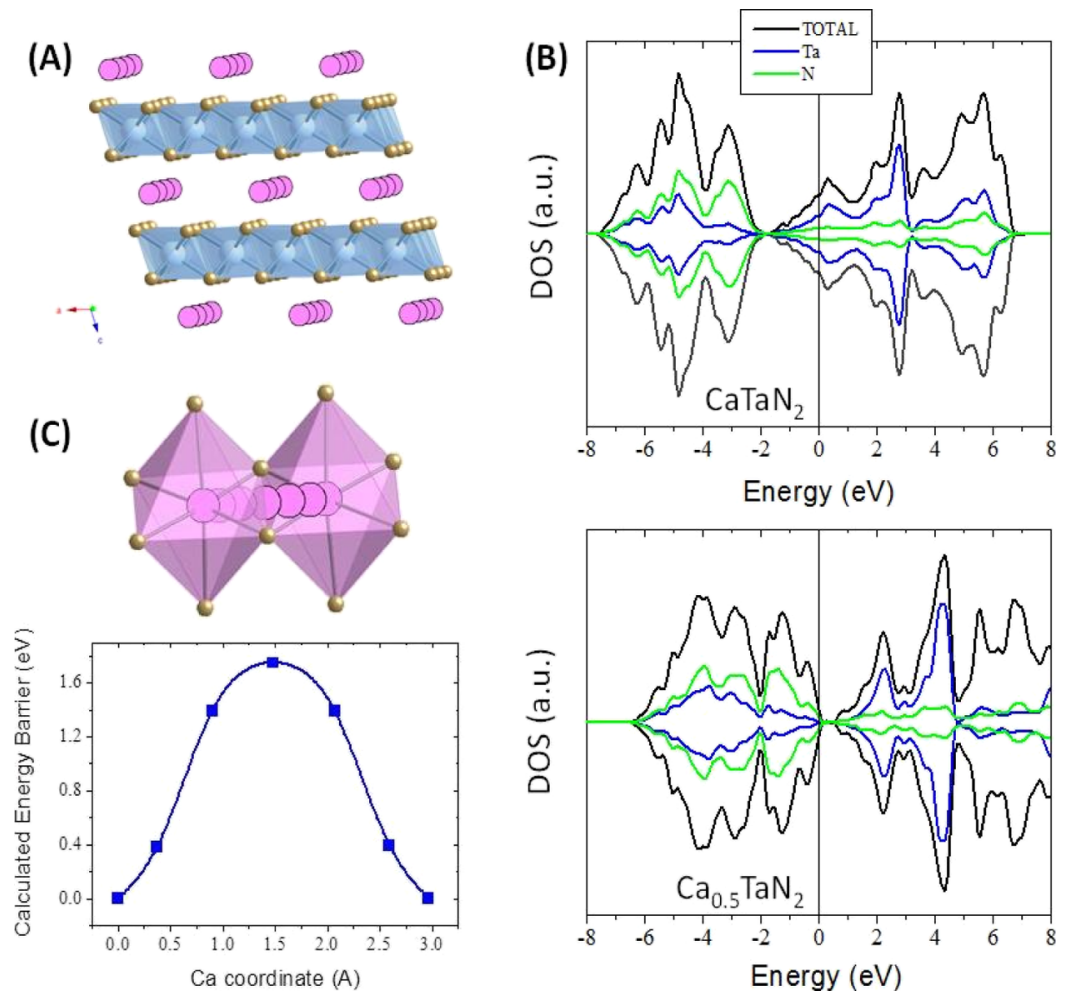

Figure 6. (A) Structural model used for the calculation of $C 2 / m-\mathrm{Ca}_{0.5} \mathrm{TaN}_{2}$. (B) Calculated DOS of monoclinic $\mathrm{Ca}_{x} \mathrm{TaN}_{2}$ with $x=1$ and $x=0.5$. The Fermi level is set as the zero of energy. (C) Diffusion pathway and calculated energy migration barrier for $\mathrm{CaTaN}_{2}\left(\mathrm{SG} \mathrm{C}_{\mathrm{T}} / \mathrm{m}\right)$.

octahedra are distorted (see Table 3), which is consistent with the monoclinic distortion observed experimentally in the pristine sample being driven by the Ca-vacancy ordering. ${ }^{47}$ Confrontation of the calculated data given in Table 3 to the experimentally achieved values, $(a=5.4182(4), b=3.1416(2)$, $c=5.9428(4) \AA$ and $\left.\beta=108.18(3)^{\circ}\right) d(\mathrm{Ta}-\mathrm{N})=2.18(3) \AA$, $d(\mathrm{Ca}-\mathrm{N})=2.47(2)$, are consistent with the Ca content $(x)$ in the as-prepared $\mathrm{Ca}_{x} \mathrm{TaN}_{2}$ being between 0.5 and 1 as experimentally observed.

Upon Ca deintercalation from $\mathrm{CaTaN}_{2}$, electrons should be removed from the band structure. The calculated density of states (DOSs) for $\mathrm{CaTaN}_{2}$ (Figure 6B) shows that the $\mathrm{N}(2 \mathrm{p}$ ) and $\mathrm{Ta}(5 \mathrm{~d})$ states largely hybridize below the Fermi level suggesting strong covalent bonding in within the $\mathrm{TaN}_{2}$ layers. As previously reported, ${ }^{43-45} \mathrm{CaTaN}_{2}$ is a bidimensional metal (no localized JT active $\mathrm{Ta} \mathrm{d}^{1}$ cations) with the $\mathrm{Ca}$ ions ionically bonded to the $\left(\mathrm{TaN}_{2}\right)^{2-}$ layers. Two wide bands appear in the DOS: the upper and partially filled band dominated by the $\mathrm{Ta}$ d-states and the lower band (between -2 and $-7 \mathrm{eV}$ ) which is mostly of $\mathrm{N} p$ character. $\mathrm{Ca}$ deintercalation from $\mathrm{CaTaN}_{2}$ to form $\mathrm{Ca}_{0.5} \mathrm{TaN}_{2}$ would imply the upper band, this is to say, the oxidation from the formal state $\mathrm{Ta}^{4+}$ to $\mathrm{Ta}^{5+}$. Beyond the $\mathrm{Ca}_{0.5} \mathrm{TaN}_{2}$ composition (or $\mathrm{NaTaN}_{2}$ for the analogous phase), Ca de-insertion would reduce the occupancy of the lower $\mathrm{N}(2 \mathrm{p})$-band producing a large amount of holes and in the end nitrogen oxidation with concomitant structural degradation.

Yet, and in line with the experimental findings discussed above, a mechanism for $\mathrm{CaTaN}_{2}$ oxidation additional and/or alternative to deintercalation should also be considered. Thus, one can postulate possible oxidation/decomposition reactions for $\mathrm{Ca}_{x} \mathrm{TaN}_{2}$ yielding other known phases in the $\mathrm{Ca}-\mathrm{Ta}-\mathrm{N}$ system, which are the potential stable phases according to the calculated phase diagram in the Materials Project database. ${ }^{48,49}$ The calculated total energies for such reactions are

$$
\begin{array}{lc}
\mathrm{CaTaN}_{2} \rightarrow 1 / 2 \mathrm{Ca}_{2} \mathrm{TaN}_{3}+1 / 2 \mathrm{TaN} & E=0.27 \mathrm{eV} \\
\mathrm{Ca}_{0.5} \mathrm{TaN}_{2} \rightarrow 1 / 4 \mathrm{Ca}_{2} \mathrm{TaN}_{3}+1 / 4 \mathrm{Ta}_{3} \mathrm{~N}_{5} & E=-0.023 \mathrm{eV}
\end{array}
$$

While $\mathrm{CaTaN}_{2}$ is predicted as a stable phase in the ternary $\mathrm{Ca}-\mathrm{Ta}-\mathrm{N}$ phase diagram at $0 \mathrm{~K}$, the negative total energy of reaction 2 reflects the thermodynamic trend of $\mathrm{Ca}_{0.5} \mathrm{TaN}_{2}$ to decompose. Moreover, under the severe oxidizing conditions employed, the formation of oxygen containing alternative phases cannot be completely excluded either. 
Finally, it should be noted that deintercalation of $\mathrm{Ca}$ ions from $\mathrm{CaTaN}_{2}$ would require them to migrate in the space between the $\left(\mathrm{TaN}_{2}\right)^{2-}$ layers. The simplest pathway for Ca diffusion in the structure is the octahedral-tetrahedraloctahedral hopping mechanism in the Ca layer (see Figure $6 \mathrm{C})$. The large calculated energy barrier $(1.7 \mathrm{eV})$ is indicative of a hampered $\mathrm{Ca}$ diffusion. Thus, it seems that other oxidation/decomposition reactions which may involve evolution of $\mathrm{N}_{2}$ (as suggested by the decrease in $\mathrm{N}$ content from 10.5 to $7.7 \%$ revealed by EDX) are likely to occur instead or concomitant to deintercalation. These would most likely be related to the progressive amorphization observed upon oxidation.

\section{CONCLUSIONS}

Ternary phases in the $\mathrm{Ca}-\mathrm{Mg}-\mathrm{Ta}-\mathrm{N}$ system with different compositions and crystal structures can be easily prepared by a proper tuning of the binary nitride precursors ratio and by using excess amounts of the alkaline earth metal in order to compensate its losses during the high temperature treatments. The extraction of $\mathrm{Ca}$ and $\mathrm{Mg}$ ions from the ternary nitrides was attempted both by chemically and electrochemically. Oxidation of $\mathrm{MgTa}_{2} \mathrm{~N}_{3}$ and $\mathrm{Mg}_{2} \mathrm{Ta}_{2} \mathrm{~N}_{4}$ could not be achieved, with the observed electrochemical capacity arising from parasitic side reactions involving the electrolyte, exacerbated at $100{ }^{\circ} \mathrm{C}$ when compared to RT. In contrast, oxidation of $\mathrm{Ca}_{0.89} \mathrm{TaN}_{2}$ was found to be possible both chemically and electrochemically. Unfortunately, this process was found to be irreversible. The differences observed in the behavior of $\mathrm{Ca}$ and $\mathrm{Mg}$ phases cannot easily be rationalized, as the crystal structures are significantly different. According to DFT calculations, the covalent $\left(\mathrm{TaN}_{2}\right)^{2-}$ in the $\mathrm{Ca}_{x} \mathrm{TaN}_{2}$ crystal structure might be oxidized to some extent, while for $\mathrm{Mg}_{2} \mathrm{Ta}_{2} \mathrm{~N}_{4}$, the disorder of $\mathrm{Mg}$ and $\mathrm{Ta}$ ions would most likely disrupt the formation of an analogous band structure.

Overall, the present work represents an additional step in multivalent cathode exploration. Indeed, despite the unsuccessful results, ternary nitrides constitute an interesting alternative to oxides, as the electrons compensating multivalent intercalation are donated to a wider band arising from the strong covalent interaction between the $\mathrm{N} p$ states and the transition metal ion, which, as inferred from DFT calculations, may result in redox processes and hence lead to high energy densities.

\section{EXPERIMENTAL SECTION}

4.1. Synthesis. All samples were prepared in batches of $250 \mathrm{mg}$. Commercial $\mathrm{Mg}_{3} \mathrm{~N}_{2}$ (Sigma-Aldrich, >99.5\%) and $\mathrm{Ca}_{3} \mathrm{~N}_{2}$ (Sigma-Aldrich, >99.5\%) and $\mathrm{Ta}_{3} \mathrm{~N}_{5}$ were used as reactants. $\mathrm{Ta}_{3} \mathrm{~N}_{5}$ was prepared by ammonolysis of $\mathrm{Ta}_{2} \mathrm{O}_{5}$ (Sigma-Aldrich, $>99.5 \%$ ), through two repeated treatments at $850{ }^{\circ} \mathrm{C}$ for $15 \mathrm{~h}$, under a $\mathrm{NH}_{3}$ flow of $600 \mathrm{~cm}^{3} / \mathrm{min}$, using 300 ${ }^{\circ} \mathrm{C} / \mathrm{h}$ heating rate and natural cooling in the furnace. All the manipulations of the nitride reactants were carried out in a glovebox under an Ar atmosphere.

CaTaN $N_{2}$ was prepared by mixing $\mathrm{Ca}_{3} \mathrm{~N}_{2}$ and $\mathrm{Ta}_{3} \mathrm{~N}_{5}$ using a $15 \%(\mathrm{w} / \mathrm{w})$ excess of $\mathrm{Ca}_{3} \mathrm{~N}_{2}$. For the synthesis of $\mathrm{Mg}_{2} \mathrm{Ta}_{2} \mathrm{~N}_{4}$, $\mathrm{Mg}_{3} \mathrm{~N}_{2}$ and $\mathrm{Ta}_{3} \mathrm{~N}_{5}$ were mixed in 1:1 stoichiometric ratios while a 1.2:2 ratio was used for the preparation of $\mathrm{MgTa}_{2} \mathrm{~N}_{3}$. After grinding, the reactant powders were pressed into pellets at 10 ton and annealed for $20 \mathrm{~h}$ under flowing $\mathrm{N}_{2}$ (Air Products, ALPHAGAZ, >99.9999\%) atmosphere. Temper- atures of 1080,850 , and $1100{ }^{\circ} \mathrm{C}$ were employed for the synthesis of $\mathrm{CaTaN}_{2}, \mathrm{MgTa}_{2} \mathrm{~N}_{3}$, and $\mathrm{Mg}_{2} \mathrm{Ta}_{2} \mathrm{~N}_{4}$, respectively, with $300{ }^{\circ} \mathrm{C} / \mathrm{h}$ heating rate. After the thermal treatment, the samples were naturally cooled in the furnace. All the thermal treatments were carried out in Mo (Alfa Aesar, 99.95\%) crucibles inside a silica tube, using $\mathrm{Zr}$ foil (Goodfellow, 99.2\%) as sample holder caps and tube inlet traps in order to avoid water and oxygen contaminations.

4.2. Structural, Morphological, and Composition Characterization. X-ray powder diffraction data were acquired using borosilicate glass capillaries of 0.3 or $0.5 \mathrm{~mm}$ diameter as sample holders. Laboratory X-ray powder diffraction data were collected using a Bruker D8 Advance A25 diffractometer in a Debye Scherrer configuration equipped with Mo K $\alpha_{1}$ radiation source $(\lambda=0.7093 \AA)$ and Johansson monochromator. Synchrotron X-ray powder diffraction (SXRPD) patterns were collected at the MSPD beamline ${ }^{19}$ of ALBA Synchrotron light source (Cerdanyola del Vallès, Spain) using mythen bank of detectors with $\lambda=0.6199 \AA$ $\left(\mathrm{MgTa}_{2} \mathrm{~N}_{3}\right.$ and $\left.\mathrm{Mg}_{2} \mathrm{Ta}_{2} \mathrm{~N}_{4}\right)$ or $0.41338 \AA\left(\mathrm{Ca}_{x} \mathrm{TaN}_{2}\right)$. The capillaries were rotated during data acquisition. Rietveld refinements were performed using the program FullProf. ${ }^{20}$

The amorphous content of $\mathrm{Ca}_{x} \mathrm{TaN}_{2}$ was determined by fullquantitative analysis, adding to the samples a known amount $(20 \% \mathrm{wt})$ of purely crystalline $\mathrm{SiO}_{2}$ standard. ${ }^{21}$

$\mathrm{N}$ contents were determined by combustion analysis in oxygen in a Thermo Fisher Scientific instrument, heating the samples in oxygen up to $1060{ }^{\circ} \mathrm{C}$.

SEM images and EDX analyses were performed by using an FEI Quanta 200 FEG microscope under high vacuum operating at $20 \mathrm{kV}$; secondary and backscattered electron detectors were used. EDX elemental mappings of $\mathrm{Mg}, \mathrm{Ca}$, and Ta were carried out over a representative area of the samples and quantitative atomic ratios were inferred accordingly.

Selected area electron diffraction was carried out by using a JEOL 1210 transmission electron microscope operating at 120 $\mathrm{kV}$, equipped with a Gatan double tilt sample holder, with typically 20 crystals being examined per sample. The powder samples were finely dispersed in ACN and deposited as droplets on carbon-coated films supported on copper grids.

4.3. Chemical and Electrochemical Oxidation Tests. Chemical oxidation tests were performed by reacting $200 \mathrm{mg}$ of the sample with $\mathrm{NO}_{2} \mathrm{BF}_{4}$ (Alfa Aesar, 96\%) in 1:4 mol $/ \mathrm{mol}$ ratio, in $50 \mathrm{~mL}$ of anhydrous ACN (Alfa Aesar, 98\%). The reaction was carried out under reflux, with continuous $\mathrm{Ar}$ bubbling within the reaction vessel. After $10 \mathrm{~h}$, the obtained dispersion was vacuum-filtered and the collected powder was rinsed with anhydrous $\mathrm{ACN}$ and dried under vacuum before being subjected to XRD analysis.

Electrochemical oxidation tests were carried out in threeelectrode Swagelok cells, by using metal discs $(\mathrm{Li}, \mathrm{Mg}$, or $\mathrm{Ca}$ ) as counter and reference electrode and the active phase as working electrode either as a powder mixture $(85: 15 \% \mathrm{w} / \mathrm{w})$ with Super P carbon or as tape (with $80 \%$ wt of active material, $10 \%$ wt of Super P carbon and $10 \%$ wt of polyvinylidene fluoride binder). $\mathrm{Al}$ and stainless steel current collectors were used for the working and reference/counter electrodes, respectively, and Whatman glass fiber discs soaked in $0.6 \mathrm{~mL}$ of electrolyte solution were used as separators.

$\mathrm{LiPF}_{6}(1 \mathrm{M})$ in EC/dimethyl carbonate (DMC) (1:1 vol, LP30 Sigma-Aldrich) and home-prepared $1 \mathrm{~m}$ LiBOB in EC/ PC (1:1 vol) electrolytes were used as electrolyte solutions for the tests carried out in $\mathrm{Li}$ cells at RT and $100{ }^{\circ} \mathrm{C}$, respectively. 
The use of Li cell configurations for the tests aiming to oxidize magnesium ternary nitride phases stems from the impossibility to achieve $\mathrm{Mg}$ plating at the counter electrode in the alkyl carbonate-based electrolyte employed. In contrast, the $\mathrm{Li}$ and $\mathrm{Ca}$ electrolytes used enabled, respectively, $\mathrm{Li}$ and $\mathrm{Ca}$ metal plating at the counter electrode, thus allowing reliable measurements. Dry $\left(<50 \mathrm{ppm} \mathrm{H}_{2} \mathrm{O}\right), 0.3 \mathrm{M}$ magnesium bis trifluoromethane sulphonyl imide $\left(\mathrm{Mg}(\mathrm{TFSI})_{2}\right.$, Solvionic, 99.5\%) in a 1:1 vol mixture of EC (Sigma-Aldrich, 99\%) and PC (Solvionic, 99.9\%) was used as electrolyte for the reduction (magnesiation) tests carried out in $\mathrm{Mg}$ cells. Ca metal threeelectrode cells and $0.45 \mathrm{M} \mathrm{Ca}\left(\mathrm{BF}_{4}\right)_{2}$ in $\mathrm{EC} / \mathrm{PC}(1: 1 \mathrm{vol})$ electrolyte with $\mathrm{H}_{2} \mathrm{O}$ content $<25 \mathrm{ppm}$ were used for the electrochemical tests on $\mathrm{CaTaN}_{2}$. Galvanostatic cycling with potential limitation (GCPL) and EPS steps tests were run on a Bio-Logic VMP3 and MPG2 potentiostat/galvanostat. Potential steps of $5 \mathrm{mV}$ and current threshold of $\mathrm{C} / 100$ (equivalent to intercalation of $1 \mathrm{~mol}$ of divalent ions in $100 \mathrm{~h}$ ) and $\mathrm{C} / 100$ rate were used in the EPS and GCPL tests, respectively. A temperature equilibration of $5 \mathrm{~h}$ at the open circuit potential was completed prior to measurements. The active material mass loadings were of about 3-4 mg.

Once tested, the cells were disassembled in an Ar-filled dry box and the electrodes or active material powder were washed with DMC solvent (Sigma-Aldrich, $\geq 99 \%$ ) before being dried and sealed in borosilicate glass capillaries for the ex situ XRD measurements.

4.4. Computational. First-principles calculations have been performed using the ab initio total-energy and molecular dynamics program Vienna $\mathrm{Ab}$ initio Simulation Program (VASP) developed at the Universität Wien. ${ }^{22}$ Total energy calculations based on DFT were performed for $\mathrm{CaTaN}_{2}$ within the general gradient approximation, with the exchange and correlation functional form developed by Perdew, Burke, and Ernzerhof. $^{23}$ The interaction of core electrons with the nuclei is described by the projector augmented wave method. ${ }^{24}$ The pseudopotentials used were Ca sv $\left(3 s^{2} p^{6} 4 s^{2}\right)$, Ta sv $\left(5 p^{6} 6 s^{2} 5 d^{3}\right)$, and $N\left(2 s^{2} p^{3}\right)$. The energy cut off for the plane wave basis set was kept fix at a constant value of $600 \mathrm{eV}$ throughout the calculations. The integration in the Brillouin zone is done on an appropriate set of $k$-points determined by the Monkhorst-Pack scheme. A convergence of the total energy close to $10 \mathrm{meV}$ per formula unit is achieved with such parameters. All calculations are spin-polarized. The initial positions for $\mathrm{CaTaN}_{2}$ models were taken from $\mathrm{Na}_{0.5} \mathrm{FeO}_{2}$ (C2/ $m)$ and delafossite- $\mathrm{NaFeO}_{2}(R \overline{3} m){ }^{25}$ All crystal structures were fully relaxed (atomic positions, cell parameters, and volume). The final energies of the optimized geometries were recalculated to correct the changes in the basis set of wave functions during relaxation. To investigate diffusion, the energy barriers for $\mathrm{Ca}$ hops between adjacent octahedral sites in $\mathrm{C} 2$ / $m-\mathrm{CaTaN}_{2}$ were calculated using the nudged elastic band method as implemented in VASP. A Ca ${ }_{17} \mathrm{Ta}_{18} \mathrm{~N}_{36}$ supercell was considered, where one $\mathrm{Ca}$ atom has been removed leaving a vacant octahedral site. Constant volume calculations were performed for five intermediate images. To calculate the energy at the saddle point, cubic splines were fit through the images along each hop.

\section{ASSOCIATED CONTENT}

\section{Supporting Information}

The Supporting Information is available free of charge on the ACS Publications website at DOI: 10.1021/acsomega.9b00770.

Observed and calculated SXRPD patterns; SEM micrographs; and EDX mappings (PDF)

\section{AUTHOR INFORMATION}

\section{Corresponding Authors}

*E-mail: amparo.fuertes@icmab.es (A.F.).

*E-mail: rosa.palacin@icmab.es (M.R.P.).

ORCID

Carlos Frontera: 0000-0002-0091-4756

Maria Elena Arroyo-de Dompablo: 0000-0001-5249-3562

Amparo Fuertes: 0000-0001-5338-9724

M. Rosa Palacín: 0000-0001-7351-2005

Notes

The authors declare no competing financial interest.

\section{ACKNOWLEDGMENTS}

The authors acknowledge funding from Ministry of Science, Innovation and Universities through grant MAT2017-86616-R, from the "Severo Ochoa" Programme for Centres of Excellence in R\&D (SEV-2015-0496), and from Generalitat de Catalunya (grant 2017SGR581). Funding from the European Union's Horizon 2020 research and innovation program H2020 FETOPEN-1-2016-2017 (CARBAT, grant agreement no. 766617) is also acknowledged. We are grateful to ALBA synchrotron for beamtime allocation at MSPD beamline (proposal 2016021576) and to Dr. François Fauth for his assistance during data collection.

\section{REFERENCES}

(1) Canepa, P.; Sai Gautam, G.; Hannah, D. C.; Malik, R.; Liu, M.; Gallagher, K. G.; Persson, K. A.; Ceder, G. Odyssey of Multivalent Cathode Materials: Open Questions and Future Challenges. Chem. Rev. 2017, 117, 4287-4341.

(2) Muldoon, J.; Bucur, C. B.; Gregory, T. Quest for Nonaqueous Multivalent Secondary Batteries: Magnesium and Beyond. Chem. Rev. 2014, 114, 11683-11720.

(3) Ponrouch, A.; Palacin, M. R. On the Road toward CalciumBased Batteries. Curr. Opin. Electrochem. 2018, 9, 1-7.

(4) Aurbach, D.; Lu, Z.; Schechter, A.; Gofer, Y.; Gizbar, H.; Turgeman, R.; Cohen, Y.; Moshkovich, M.; Levi, E. Prototype Systems for Rechargeable Magnesium Batteries. Nature 2000, 407, 724-727.

(5) Ponrouch, A.; Frontera, C.; Bardé, F.; Palacín, M. R. Towards a Calcium-Based Rechargeable Battery. Nat. Mater. 2016, 15, 169-172.

(6) Wang, D.; Gao, X.; Chen, Y.; Jin, L.; Kuss, C.; Bruce, P. G. Plating and Stripping Calcium in an Organic Electrolyte. Nat. Mater. 2018, 17, 16-20.

(7) Tchitchekova, D. S.; Ponrouch, A.; Verrelli, R.; Broux, T.; Frontera, C.; Sorrentino, A.; Bardé, F.; Biskup, N.; Arroyo-de Dompablo, M. E.; Palacín, M. R. On the Electrochemical Intercalation of Calcium and Magnesium in $\mathrm{TiS}_{2}$ : Fundamental Studies Related to Multivalent Battery Applications. Chem. Mater. 2018, 30, 847-856.

(8) Verrelli, R.; Black, A. P.; Pattanathummasid, C.; Tchitchekova, D. S.; Ponrouch, A.; Oró-Solé, J.; Frontera, C.; Bardé, F.; Rozier, P.; Palacín, M. R. On the Strange Case of Divalent Ions Intercalation in $\mathrm{V}_{2} \mathrm{O}_{5}$. J. Power Sources 2018, 407, 162-172.

(9) Cabello, M.; Nacimiento, F.; Alcántara, R.; Lavela, P.; Pérez Vicente, C.; Tirado, J. L. On the Applicability of Molybdite as an 
Electrode Material in Calcium Batteries: A Structural Study of LayerType $\mathrm{Ca}_{x} \mathrm{MoO}_{3}$. Chem. Mater. 2018, 30, 5853-5861.

(10) Dompablo, M. E. A.-d.; Krich, C.; Nava-Avendaño, J.; Biškup, N.; Palacín, M. R.; Bardé, F. A Joint Computational and Experimental Evaluation of $\mathrm{CaMn}_{2} \mathrm{O}_{4}$ Polymorphs as Cathode Materials for Ca Ion Batteries. Chem. Mater. 2016, 28, 6886-6893.

(11) Tchitchekova, D. S.; Frontera, C.; Ponrouch, A.; Krich, C.; Bardé, F.; Palacín, M. R. Electrochemical Calcium Extraction from 1D- $\mathrm{Ca}_{3} \mathrm{Co}_{2} \mathrm{O}_{6}$. Dalton Trans. 2018, 47, 11298-11302.

(12) Fuertes, A. Metal oxynitrides as emerging materials with photocatalytic and electronic properties. Mater. Horiz. 2015, 2, 453461.

(13) Bonnick, P.; Blanc, L.; Vajargah, S. H.; Lee, C.-W.; Sun, X.; Balasubramanian, M.; Nazar, L. F. Insights into Mg2+Intercalation in a Zero-Strain Material: Thiospinel $\mathrm{Mg}_{x} \mathrm{Zr}_{2} \mathrm{~S}_{4}$. Chem. Mater. 2018, 30, $4683-4693$.

(14) Sun, X.; Bonnick, P.; Duffort, V.; Liu, M.; Rong, Z.; Persson, K. A.; Ceder, G.; Nazar, L. F. A high capacity thiospinel cathode for $\mathrm{Mg}$ batteries. Energy Environ. Sci. 2016, 9, 2273-2277.

(15) Elder, S. H.; Doerrer, L. H.; Disalvo, F. J.; Parise, J. B.; Guyomard, D.; Tarascon, J. M. Lithium molybdenum nitride $\left(\mathrm{LiMoN}_{2}\right)$ : The 1st Metallic Layered Nitride. Chem. Mater. 1992, 4, 928-937.

(16) Verrelli, R.; Arroyo-de-Dompablo, M. E.; Tchitchekova, D.; Black, A. P.; Frontera, C.; Fuertes, A.; Palacin, M. R. On the Viability of $\mathrm{Mg}$ Extraction in MgMoN2: A Combined Experimental and Theoretical Approach. Phys. Chem. Chem. Phys. 2017, 19, 2643526441.

(17) Brokamp, T.; Jacobs, H. Darstellung und Struktur einiger Gemischtvalenter ternärer Tantalnitride mit Lithium und Magnesium. J. Alloys Compd. 1992, 183, 325-344.

(18) Balbarin, V.; Van Dover, R. B.; Disalvo, F. J. The High Temperature Preparation and Property Measurements of $\mathrm{CaTaN}_{2}: \mathrm{A}$ Ternary Superconducting Nitride. J. Phys. Chem. Solids 1996, 57, 1919-1927.

(19) Fauth, F.; Peral, I.; Popescu, C.; Knapp, M. The New Material Science Powder Diffraction Beamline at ALBA Synchrotron. Powder Diffr. 2013, 28, S360-S370.

(20) Rodríguez-Carvajal, J. Recent Advances in Magnetic Structure Determination by Neutron Powder Diffraction. Phys. B Condens. Matter 1993, 192, 55-69.

(21) Bish, D. L.; Howard, S. A. Quantitative Phase Analysis Using the Rietveld Method. J. Appl. Crystallogr. 1988, 21, 86-91.

(22) Kresse, G.; Furthmüller, J. Efficient iterative schemes forab initiototal-energy calculations using a plane-wave basis set. Phys. Rev. B: Condens. Matter Mater. Phys. 1996, 54, 11169-11186.

(23) Perdew, J. P.; Burke, K.; Ernzerhof, M. Generalized Gradient Approximation Made Simple. Phys. Rev. Lett. 1996, 77, 3865-3868.

(24) Blöchl, P. E. Projector Augmented-Wave Method. Phys. Rev. B: Condens. Matter Mater. Phys. 1994, 50, 17953-17979.

(25) Takeda, Y.; Nakahara, K.; Nishijima, M.; Imanishi, N.; Yamamoto, O.; Takano, M.; Kanno, R.; Takano, M.; Kanno, R. Sodium Deintercalation from Sodium Iron Oxide. Mater. Res. Bull. 1994, 29, 659-666.

(26) McHale, J. M.; Navrotsky, A.; Kowach, G. R.; Balbarin, V. E.; Disalvo, F. J. Energetics of Ternary Nitrides: $\mathrm{Li}-\mathrm{Ca}-\mathrm{Zn}-\mathrm{N}$ and $\mathrm{Ca}-$ Ta-N Systems. Chem. Mater. 1997, 9, 1538-1546.

(27) Niewa, R.; Jacobs, H. Group V and VI Alkali Nitridometalates: A Growing Class of Compounds with Structures Related to Silicate Chemistry. Chem. Rev. 1996, 96, 2053-2062.

(28) DiSalvo, F. J.; Clarke, S. J. Ternary Nitrides: A Rapidly Growing Class of New Materials. Curr. Opin. Solid State Mater. Sci. 1996, 1, 241-249.

(29) Gregory, D. H.; Gregory, D. H. Structural Families in Nitride Chemistry. J. Chem. Soc., Dalton Trans. 1999, 259-270.

(30) Yamane, H.; DiSalvo, F. J. Sodium Flux Synthesis of Nitrides. Prog. Solid State Chem. 2018, 51, 27-40.
(31) Wachsmann, C.; Brokamp, T.; Jacobs, H. Darstellung Und Struktur Eines Neuen Nitridoxides Mit Lithium Und Tantal: $\mathrm{Li}_{16} \mathrm{Ta}_{2} \mathrm{~N}_{8}$ O. J. Alloys Compd. 1992, 185, 109-119.

(32) Serrano-Sevillano, J.; Reynaud, M.; Saracibar, A.; Altantzis, T.; Bals, S.; Van Tendeloo, G.; Casas-Cabanas, M. Enhanced Electrochemical Performance of Li-Rich Cathode Materials through Microstructural Control. Phys. Chem. Chem. Phys. 2018, 20, 2311223122.

(33) Jacobs, H.; von Pinkowski, E. Synthese Ternärer Nitride von Alkalimetallen: Verbindungen Mit Tantal, $\mathrm{MTaN}_{2}$ Mit $\mathrm{M} \equiv \mathrm{Na}, \mathrm{K}$, $\mathrm{Rb}$ Und Cs. J. Less Common Met. 1989, 146, 147-160.

(34) Marianetti, C. A.; Ceder, G.; Morgan, D. First-Principles Investigation of the Cooperative Jahn-Teller Effect for Octahedrally Coordinated Transition-Metal Ions. Phys. Rev. B: Condens. Matter Mater. Phys. 2001, 63, 224304.

(35) Radin, M. D.; Alvarado, J.; Meng, Y. S.; Van Der Ven, A. Role of Crystal Symmetry in the Reversibility of Stacking-Sequence Changes in Layered Intercalation Electrodes. Nano Lett. 2017, 17, 7789-7795.

(36) Shao-Horn, Y.; Levasseur, S.; Weill, F.; Delmas, C. Probing Lithium and Vacancy Ordering in $\mathrm{O} 3$ Layered $\mathrm{Li}_{x} \mathrm{CoO}_{2}(\mathrm{X} \approx 0.5)$. J. Electrochem. Soc. 2003, 150, A366.

(37) Ceder, G.; Van der Ven, A. Phase Diagrams of Lithium Transition Metal Oxides: Investigations from First Principles. Electrochim. Acta 1999, 45, 131-150.

(38) Kaburagi, M.; Kanamori, J. Ground State Structure of Triangular Lattice Gas Model with up to 3rd Neighbor Interactions. J. Phys. Soc. Jpn. 1978, 44, 718-727.

(39) Van der Ven, A.; Aydinol, M. K.; Ceder, G.; Kresse, G.; Hafner, J. First-Principles Investigation of Phase Stability in $\mathrm{Li}_{x} \mathrm{CoO}_{2}$. Phys. Rev. B: Condens. Matter Mater. Phys. 1998, 58, 2975-2987.

(40) Arroyo y de Dompablo, M. E.; Van der Ven, A.; Ceder, G. First-Principles Calculations of Lithium Ordering and Phase Stability on $\mathrm{Li}_{x} \mathrm{NiO}_{2}$. Phys. Rev. B: Condens. Matter Mater. Phys. 2002, 66, 064112.

(41) Nishijima, M.; Tadokoro, N.; Takeda, Y.; Imanishi, N.; Yamamoto, O. Li Deintercalation-Intercalation Reaction and Structural Change in Lithium Transition Metal Nitride, $\mathrm{Li}_{7} \mathrm{MnN}_{4}$. J. Electrochem. Soc. 1994, 141, 2966-2971.

(42) Didier, C.; Guignard, M.; Darriet, J.; Delmas, C. O3- $\mathrm{Na}_{x} \mathrm{VO}_{2}$ system: A Superstructure for $\mathrm{Na}_{1 / 2} \mathrm{VO}_{2}$. Inorg. Chem. 2012, 51, 11007-11016.

(43) Rauch, P. E.; DiSalvo, F. J. Ambient pressure synthesis of ternary group (V) nitrides. J. Solid State Chem. 1992, 100, 160-165.

(44) Smolinski, H.; Weber, W. Electrons and Phonons in the New 10K Superconductor $\mathrm{CaTaN}_{2}$. Z. Phys. B: Condens. Matter 1997, 104, $741-743$.

(45) Orisakwe, E.; Fontaine, B.; Gregory, D. H.; Gautier, R.; Halet, J.-F. Theoretical Study on the Structural, Electronic and Physical Properties of Layered Alkaline-Earth-Group-4 Transition-Metal Nitrides AEMN 2 . RSC Adv. 2014, 4, 31981-31987.

(46) Oliva, J. M.; Weht, R.; Ordejón, P.; Canadell, E. Electronic Structure of the Superconducting Layered Ternary Nitrides $\mathrm{CaTaN}_{2}$ and $\mathrm{CaNbN}_{2}$. Phys. Rev. B: Condens. Matter Mater. Phys. 2000, 62, $1512-1515$

(47) Arroyo y de Dompablo, M. E.; Marianetti, C.; Van der Ven, A.; Ceder, G. Jahn-Teller Mediated Ordering in Layered $\mathrm{Li}_{x} \mathrm{MO}_{2}$ Compounds. Phys. Rev. B: Condens. Matter Mater. Phys. 2001, 63, 144107.

(48) Hautier, G.; Fischer, C.; Ehrlacher, V.; Jain, A.; Ceder, G. Data Mined Ionic Substitutions for the Discovery of New Compounds. Inorg. Chem. 2011, 50, 656-663.

(49) Jain, A.; Hautier, G.; Ong, S. P.; Moore, C. J.; Fischer, C. C.; Persson, K. A.; Ceder, G. Formation Enthalpies by Mixing GGA and GGA + U Calculations. Phys. Rev. B: Condens. Matter Mater. Phys. 2011, 84, 045115. 